\title{
Risk Factors for Cardiovascular Disease in Rural Area of Croatia
}

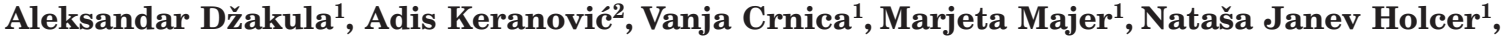 \\ Slavica Sović ${ }^{1}$, Bojana Bolić ${ }^{1}$, Nikolina Antonia Domokuš ${ }^{2}$, Ivanka Dražić ${ }^{2}$, Marija Vugrinčićc $^{2}$,

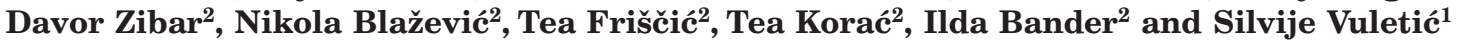 \\ ${ }^{1}$ University of Zagreb, School of Medicine, »Andrija Štampar« School of Public Health, Zagreb, Croatia \\ ${ }^{2}$ University of Zagreb, School of Medicine, Student Research Group, Zagreb, Croatia
}

\begin{abstract}
A B S T R A C T
Rural areas, where $47.6 \%$ of the Croatian population lives are not generally the focus of research; yet there are challenges which affect the rural population that often go unreported. These communities often exhibit disadvantages in many areas of health. The aim of this study is to examine the specific health needs and related determinants of rural populations influenced by transition that were affected by the consequences of war. The focus of the research is rural lifestyle, behaviour and cardiovascular risk factors in three villages of Sisačko-moslavačka County. Results show that participants generally understand that their own lifestyles influence their health, but they often neglect to change their behaviour to improve their health. This can be explained through complex socio-economic conditions and traditional values of their heritage. These results suggest a need for further research on health status, attitude, and behaviour of Croatia's rural population. Specific public health intervention and services for rural populations must be promoted.
\end{abstract}

Key words: cardiovascular disease, risk factors, rural population, health care, health status

\section{Introduction}

Rural communities exist in all parts of the world. Regardless if these communities are in Canada, United States, Australia, United Kingdom, Africa, or China, they all have diverse social, geographic, and economic characteristics. Most of these rural communities have a larger proportion of elderly, with relatively small populations of people of working age (20-50 yrs.) resulting in a higher dependency ratio. According to the Organization for Economic Co-operation and Development (OECD) criteria, based on the population density, rural area in Croatia encompasses $91.6 \%$ of the total territory with $47.6 \%$ of the total population. Croatian villages are an integral part of the rich European tradition. Furthermore, life in a rural community is one of the pillars of the historical and cultural identity. After a few decades of faster prosperity of the urban areas and extensive outflow of population from rural areas to the cities, rural areas fell out of research focus and understanding of changes which overtook rural populations ${ }^{7}$. Croatia, as a transitional country, has challenges typical for the developed countries: rising costs connected with demographic ag- ing, rising expectations concerning health care rights as well as constraints in financing health care. All these challenges were further increased in the 1990 s, when Croatia was affected by war. Recent conflict has especially affected rural areas, leading to a reduction of agricultural activities. Moreover, $40 \%$ of territory still suffers the effects of war - damages on infrastructure, presence of refugees, internal displacement of people, migration to other countries and psychological effects on the people ${ }^{7}$. It seems that in transition and war period health inequalities rise with rising social inequalities, but there is still lack of data, particularly for rural population ${ }^{8}$. Rural communities show health disadvantage for many health measures. Distance to the nearest medical facility is a serious problem faced more frequently by the rural population. Rural-urban differences in the perception of the cost of seeing the doctor were found in all countries, and in Croatia were almost twice as in EU country groups ${ }^{8,9}$.

Overall, rural health and health care are faced with a lack of adequate data, analysis and systematic knowled- 
ge. Stereotypes pertaining to a strong family and community support among rural inhabitants exist with rural settings recognized as healthier than urban. When discussing the role the rural setting has on health status and behaviour, including health services utilization, health care needs should be recognized as aggregate of interacting factors encapsulated in specific geographic locations. Rural populations live in the same environment over an extended period of time, which increases the health effects of their lifestyle. These populations have specific needs for medical care and this recognition can be of great value when studying the health effects on a populations' lifestyle. Health care research in rural populations is often limited, due to the small size and lack of infrastructure, as well as the lack of specific methodology or tools. Preliminary results of our pilot research performed in a community affected by war showed a lack of adequate data about the rural population's health status and use of health care in Croatian rural areas. Some systematic misunderstanding, particularly about health care needs and health care accessibility of rural population was recognized. Our research has shown that some commonly used research tools in public health are not fully appropriate for understanding Croatia's rural health needs. Also, there are no unique rural setting patterns in Croatia and few among them are regions affected by war.

The aim of this study was to present specific determinants of health and health needs of rural population that experienced transition, war and post-war consequences. The main focuses of the research concentrated on the risk factors and behaviors connected to cardiovascular diseases.

\section{Sample and Methods}

The research was conducted from January until March 2011 in Croatia, in Sisačko-moslavačka County. The villages included were: Mala Gradusa, Sjeverovac and Staro Selo. In order to get an intensive picture of the participants' health, quantitative and qualitative researches were conducted.

\section{Participants}

The research sample was comprised of 28 participants, 15 women (54\%) and 13 men (46\%). Survey participants were 18 years or older, living in the research area longer than 20 years, including the war period. The sample consisted of all inhabitants present at their houses at the moment of survey. The sample was composed on a door to door basis.

\section{Qualitative interview method}

Non-institutional, semi-structured interviewing with the prior consent of the respondents was used as a research method. The Interviews were approximately 1 hour in duration and conducted by trained medical students. They followed the specific habits, behaviours and perceptions of typical factors related to the country life
TABLE 1

THEMES USED DURING INTERVIEW

1. The meaning of life in the countryside for health and general attitudes about health

2. Use of health care

3. Perception of severity of illness and ailments and Perception of risks and symptoms

4. Eating habits

5. Awareness of cardiovascular disease and risks

6. Support and perceived attitude of the environment

and health concerns, following an agreed set of themes based on the literature (Table 1).

All interviews were recorded with an audio recording, according to which the transcript that was used for detailed analysis was made. The authors jointly thematically analyzed the recorded audio and transcribed conversations, reaching an agreement and validating the emerging themes. The transcripts were analyzed using detextualisation and recognition of significant categories of attitudes, behaviours or events that determine the life of the respondents.

\section{Results}

All collected interviews were processed and the content was analyzed in relation to cardiovascular diseases, risks and health care. During the analysis, particular attention was given to the content that brought specific information to the rural population. The results were organized and presented in three categories: perception of risk, habits and awareness. Every category with accompanied sentences was shown separately.

\section{Perception of risk}

Participants generally understood that their own lifestyles influence their health. However, a participant's denial that they are personally responsible for their health was a common finding.

- »I have no problem other than that brandy, I have to stop."

- »Here, we have a nice air and nice water, the most important is the clean air.

- »Only stress, sadness, loneliness and that."

- »Stress has the biggest effect on health, in young and old. But you can't avoid it.«

- »I cannot change anything, it is a chronic disease.«

\section{Habits}

Participants mostly eat home cooked meals; food they produced themselves. Due to tradition of breeding the poultry and swine, they eat a lot of meat and meat products. Mostly, there are two to three meals daily, depending on the farm workload. Snacks are rare. The type of food they eat depends on the work they are doing. 
- »Oh, you know what we are eating here, in village. Local products: dried, smoked, salty, fatty, spicy, cheese, cream (sour/heavy), eggs.«

- »In my house, we use a lot of meat. In general, in my house everyone is on enormous doses of proteins."

- "Light food in the villages does not go, especially when doing a physical job, you can't survive on light food, regardless if it affects health or not.«

Participants perceive their way of eating, based on homemade food, as healthy, but also they are aware about risks accompanied with salty and fatty food. The effect of diet (nutrition) on health is not perceived until it causes symptoms or problems.

- »I think that my diet is healthy, all is homemade. That is not the things you buy, that is sprayed, we don't spray. In the village, there is no spraying."

- "Doctor says that I should not (eat) pork, smoked meat, I think. Then what will I eat? What should I eat? It is like this in the village. I have neither stores here nor money to go buy something fresh.?. What should I do when we are used to this."

- "You eat fish less since you buy it.«

- »I did not feel that anything harms; diet. Nothing."

As a drink that is drunk the most in the village, brandy is the most prominent since they make it themselves. After the brandy mostly drunk are beer, water and juice.

- »Brandy, nothing else, just brandy. We have no other products. No vineyards to drink wine... we have the cleanest water and brandy«.

- »Someone drinks beer, someone, water, someone juice«.

- "Brandy is healthy, when you drink a shot or two. That is for the circulation, for either a male or a female."

- »I think that who drinks in moderation, I am not a doctor, but I do think that a shot of brandy can't do harm. And whose body needs."

- "No one needs more than one glass. «

- »It depends on the organism (body); someone drinks one litre and you can't notice, someone one glass and losses consciousness."

\section{Knowledge/Awareness}

Participants show a different level of knowledge and awareness about diabetes and hypertension, depending whether they are suffering from these diseases. Their main source of information about the disease is their doctor, whereas they find out about the other diseases from a media, family or a neighbour.

- »This doctor of mine, I go to her, and she explains everything nicely.«

- »For sugar (diabetes), I passed the entire educational program, without a problem, learned everything by heart."

- »I hear more at the doctor's and when people talk among each other.«
- »In general, everyone mentions it, television and the newspapers."

\section{Hypertension}

The participants show knowledge and awareness about the need to change life habits (lifestyle) and to take their therapy in case of a hypertension: nutrition/diet (can't eat fatty and salty food), decrease of the body weight, therapy compliance, avoidance of stressful situations. Hypertension is perceived as a dangerous disease.

- »To eat less, not to overeat...shouldn't drink either. To eat less fat, to stop fat."

- »To give her therapy is the most important...can't eat prosciutto (or smoked ham).«

- »To go to the doctor and to drink the medications.«

- "Supposedly it destroys the heart, destroys the kidneys and now you can't live two hundred years."

- »It can shock you.«

- »Well, it can kill a man, it can shock. It can do everything, which is dangerous."

- »Well, that is not dangerous...depends on how the body handles it. People with pressure, have a high pressure and live 90 years, and the one that does not lives $40-50$. Who can connect that?

\section{Diabetes}

Participants show awareness about the need to change habits (lifestyle) and to comply with the medication, in case they are diagnosed with diabetes. However, the knowledge about diabetes is less than about the hypertension.

- »To watch her diet, pasta (dough), bread, cakes, fats, can't even eat some fruits."

- »Administers insulin to himself... (He) sticks to the diet."

- »I do not know about the sugar (diabetes). I hear that it is not good."

- »Well, I am not familiar with that disease. My sister-in-law died from diabetes, but I do not understand that disease."

- »Everything can go because of sugar, it attacks everything, and it destroys organs, kidneys, liver, pancreas, eyes, and the eye vision."

- »The mother of my daughter-in-law, had sugar. She hit her big toe, cut herself and then they cut off her leg."

- "It is bad because you can die from it. You get wounds."

- "You have to take care of yourself more than the ones that have pressure."

- »Sugar (diabetes) is one type of cancer."

- »My husband was a diabetic and he had that classic kind, from the very beginning until the amputation, blindness; I lived through it all...When I get sugar, then I would probably change my lifestyle.«

- »You don't get sugar (diabetes) if you work and live nicely.« 


\section{Discussion}

This study produced results of qualitative and naturalistic inquiries that brought specific insights into rural lifestyle, behaviour and cardiovascular health risks. Rural populations showed an understanding of how their own lifestyles influence their health. As potentially harmful for their health, they recognize: alcohol consumption, nutrition, stress, loneliness and depression. As beneficial for their health, they recognize: clean air and water, compliance with the therapy, and adherence to the dietary guidelines. Denial of their personal responsibility for health and bigger expectations from a doctor and therapy was an occasional finding. There was an intuitive recognition for a need of »heavy» food when performing a difficult physical work. Participants perceive their way of eating as healthy on one side that the food was homemade (local) and on the other hand, that they are informed (aware) about the harm of salty and fatty foods. Despite that, they did not change their eating habits because of the "unhealthy» food they have at home, wherein they should buy healthy food instead. It is interesting that the effect of diet (nutrition) on health is not perceived until it causes symptoms or problems. Overconsumption of alcohol is defined differently by the participants, but the rule is that it means when one becomes drunk. Small amounts of brandy, one or two shots are considered as healthy and overconsumption of alcohol is perceived as unhealthy. Hypertension is perceived as a serious disease due to possible complications of cerebrovascular insult and death, myocardial infarction or kidney damage. The perception of hypertension as a non-dangerous disease is an individualized finding. Diabetes is perceived as a dangerous disease due to possible complications of amputations, loss of sight, difficulty in wound healing, and/or kidney damage. It is perceived more dangerous than hypertension therefore it is a bigger motivator for lifestyle changes. There is also a perception of personal responsibility about the cause of the disease.

Participants showed a different level of knowledge and awareness about diabetes and hypertension, depending on whether or not they are suffering from these diseases. Since most participants suffer from high blood pressure, their awareness about hypertension was greater. Their main source of information about the disease was their doctor, whereas they find out about other diseases from the television and/or their surroundings, including their family or a neighbour, or through the media-newspapers or a radio.

\section{R E F E R E N C E S}

1. UNITED STATES DEPARTMENT OF AGRICULTURE, Rural Information Center, accessed 13.02.2011. Available from: URL: http://www. nal.usda.gov/ric/ricpubs/what is rural.shtml. - 2. US DEPARTMENT ON HEALTH AND HUMAN SERVICES, Health Resources and Services Administration, accessed 13.02.2011. Available from: URL: http://www. hrsa.gov/ruralhealth/policy/index.html/. - 3. INSTITUTE OF RURAL HEALTH, accessed 13.02.2011. Available from: URL: http://www.ruralhealth.ac.uk/. - 4. AUSTRALIA'S NATIONAL AGENCY FOR HEALTH AND WELFARE STATISTICS AND INFORMATION, accessed 16.02
Although the participants showed knowledge and awareness about the need to change their lifestyle and to take their therapy, they were not willing to make changes in their behaviour. The reasons for that attitude could be explained through complex socio-economic conditions and traditional values of their heritage. The importance of these results could be recognized as a contribution to the basic research of social and environmental determinants of non-communicable diseases in rural setting. This kind of research is internationally recognized as limited.

Most of the rural populations in this study, like other rural communities, are socially deprived with low income and lower education, which commonly contributes to increased risks of cardiovascular diseases. However, high level of awareness about the risk factors and knowledge about diseases could not be explained as health illiteracy related to social deprivation. Also, this populations' basic accessibility to health care was not limited, which lead us to conclude that health care accessibility cannot be recognized as a key determinant of their unhealthy behaviour.

Results have shown that usual determinants of social deprivation are not strongly expressed and that they do not have an important influence on population's behaviour. Attitude related to rural life style and dietary habits became more important determinants. Consumption of high caloric value food is recognized as a necessity, and consumption of homemade products, especially cured meat was perceived as an acceptable diet. This behaviour is supported by the availability of cheaper homemade food, opposite to expensive and not always available healthy food, like fish, fresh fruit and vegetables during the whole year. Overall, results of this survey suggest that specific behaviours of the rural population have to be accepted and further explored.

\section{Conclusion}

There is a need to focus further research on health status, attitudes and behaviour of rural populations in Croatia. Comprehensive health setting, specific health determinants or health behaviour patterns in rural Croatia are not at present recognized. Specific public health intervention and services for rural population have to be developed. Increased investment through existing model of health care system could not change determinants related to the rural setting and lifestyle.

2011. Available from: URL: http://www.aihw.gov.au/rural-health. -5 . RURAL HEALTH WORKFORCE AUSTRALIA, accessed 16.02.2011. Available from: URL: http://www.rhwa.org.au/site/index.cfm. - 6. IRISH INSTITUTE OF RURAL HEALTH, accessed 16.02.2011. Available from: URL: http://www.rural-health.net/RrlHlth.htm/. — 7. MINISTRY OF AGRICULTURE, FISHERIES AND RURAL DEVELOPMENT, Strategy of rural development in Republic of Croatia for the period 2008-2013, accessed 13.02.2011. Available from: URL: http://www.mps.hr/default. aspx?id=13/. - 8. ŠUĆUR Z, ZRINŠČAK S, Croat Med J, 48 (2007) 653. 
- 9. PRISTAS I, BILIC M, PRISTAS I, VONCINA L, KRCMAR N, POLASEK O, STEVANOVIC R, Coll Antropol, 33 (2009) Suppl. 1: 121. - 10. Combating poverty and social exclusion in rural areas: key findings and key questions, report of the conference. In: Proceddings (Budapest, June 11-12 2009). - 11. DESMEULES M, PONG R, LAGACÉ C, HENG D, MANUEL D, PITBLADO R, BOLLMAN R, GUERNSEY J, KAZANJIAN A, KOREN I, Canadian Institute for Health Information (Ottawa, Ontario, 2006). - 12. IGL W, JOHANSSON A, GYLLENSTEN U, Rural and Remote Health, 10 (2010), accessed 16.02.2011. Available from: URL: http://www.rrh.org.au/publishedarticles/article_print_1363.pdf/. - 13 KERANOVIC A, DRAŽIĆ I, GARDIJAN B, KRIZANČIĆ J, MODRIĆ Ž, VRKLJAN AM, SOVIĆ S, JELAKOVIĆ B, Specific hypertension issues experienced by a rural community - experience gained in the Sisak-moslavina county. In: Proceedings (Second Croatian preventive medicine and health promotion, Croatian Society for Public health, Zagreb, 2010). - 14. BLAŽEVIĆ N. BOŠNJAK D, PRIPUŽIĆ M, POLJIĆANIN T, Prevalence of diabetes in rural areas of the Sisak-moslavina county. In: Proceedings (Second Croatian preventive medicine and health promotion Croatian Society for Public health, Zagreb, 2010). - 15. BÖHM T, ZIBAR D, TIPURA D, POLJIČANIN T, Prevalence of hypertension in diabetic members of the rural population of the Sisak-moslavina county. In: Proceedings (Second Croatian preventive medicine and health promotion, Croatian Society for Public health, Zagreb, 2010). - 16. FRIŠČĆĆ T, PELIN M, VUGRINČIĆ M, MEŠTOVIĆ M. ŠTIMAC D, DŽAKULA A, Health of women populating rural areas of the Sisak-moslavina county In: Proceedings (Second Croatian preventive medicine and health promotion, Croatian Society for Public health, Zagreb, 2010). - 17. ZIBAR D KERANOVIĆ A, VARJAČIĆ T, MIŠE J, BLAŽEVIĆ N, VRKLJAN AM, GARDIJAN B, VITALE K, SOVIĆ S, JANEV HOLCER N, VULETIĆ S, DŽAKULA A, What does rural dwelling actually imply when it comes to the republic of Croatia - Sisak-moslavina county model. In: Proceedings (Second Croatian preventive medicine and health promotion, Croatian Society for Public health, Zagreb, 2010). - 18. HALMI A, Kvalitativna metodologija u društvenim znanostima (A. G. Matoš, Samobor, 1996). 19. WHO Regional Office for Europe, Rural poverty and health systems in the WHO European Region, accessed 14.02.011. Available from: URL http://www.euro.who.int/en/what-we-publish/abstracts/rural-poverty-and-health-systems-in-the-who-european-region/. - 20. ZAHND WE SCAIFE SL, FRANCIS, Am J Health Behav, 33 (2009) Suppl. 5 : 550.

\section{A. Džakula}

University of Zagreb, School of Medicine, „Andrija Štampar" School of Public Health, Rockefellerova 4, 10000 Zagreb, Croatia

e-mail:adzakula@snz.hr

\section{RIZIČNI ČIMBENICI ZA NASTANAK KARDIOVASKULARNIH BOLESTI U RURALNIM PODRUČJIMA U HRVATSKOJ}

\section{S A Ž E T A K}

Ruralna područja u kojima živi 47,6\% hrvatske populacije ostala su izvan istraživačkog fokusa i prepoznavanja promjena karakterističnih za ruralno stanovništvo. U ruralnim zajednicama utvrđeno je lošije zdravstveno stanje u više dimenzija. Cilj je ovog istraživanja utvrditi specifične zdravstvene potrebe i pripadajuće čimbenike koji odražavaju utjecaj rata, posljedica rata i tranzicije na ruralno stanovništvo. Fokus istraživanja usmjeren je na ruralni stil života, ponašanje i kardiovaskularne rizične čimbenike u tri sela Sisačko-moslavačke županije. Rezultati pokazuju da ispitanici razumiju da njihov životni stil utječe na njihovo zdravlje, ali ne prihvaćaju promjenu vlastitog ponašanja, što se može objasniti složenim socio-ekonomskim okolnostima i tradicijskim vrijednostima vezanim uz njihovo nasljeđe. Rezultati ukazuju na potrebu da se dalje specifično istražuje zdravstveno stanje, stavovi i ponašanje ruralne populacije u Hrvatskoj. Potrebno je razviti specifične javnozdravstvene intervencije i skrb za ruralno stanovništvo. 